\title{
PENGARUH MINAT BELAJAR SISWA TERHADAP HASIL BELAJAR TRIGONOMETRI
}

\author{
Nadun \\ Program Studi Pendidikan Matematika, FMIPA, Universitas Indraprasta PGRI
}

\section{INFO ARTICLES}

\section{Article History:}

Received: 22 Agustus 2017

Revised: 22 September 2017

Approved: 15 Oktober 2017

Publish Online: 7 November 2017

\section{Key Words:}

Student's Interest, Result of Learning Trigonometry

\section{(†) (2)}

This article is licensed Commons AttributionShareAlike 4.0 International License.

\begin{abstract}
This research aims to know the influence of interest in learning mathematics achievement. The benefits of this research is to analyze the effect of minatterhadap the achievements of learning math. The methods used in this study is the analysis of the comparison with the present exposé performed on class X students in SMK Negeri 1 Cikarang Barat, Kab. Bekasi. The sample in this research totalled 67 people were taken with learners how random population of as many as 207 affordable learner people. The instruments used in the form of the now 30-grain statements and already validated in empirical. Data analysis the results of research done in a descriptive and inferensial use "test " $t$, with the first test of its homogeneity and normality. Based on data processing, obtained summary there are significant effects of interest to learning achievements learning mathematics in class $X$ students in SMK Negeri 1 Cikarang Barat, Kab. Bekasi, West Java. This can be evidenced by the acquisition value t_hitung >t_tabel $6.610>1.960$.
\end{abstract}

Abstrak: Penelitian ini bertujuan untuk mengetahui pengaruh minat terhadap prestasi belajar matematika. Manfaat dari penelitian ini adalah untuk menganalisis pengaruh minatterhadap prestasi belajar matematika. Metode yang digunakan dalam penelitian ini adalah expose facto dengan analisis komparasi yang dilakukan pada peserta didik kelas X di SMK Negeri 1 Cikarang Barat, Kab. Bekasi. Sampel dalam penelitian ini berjumlah 67 orang peserta didik yang diambil dengan cara random dari populasi terjangkau sebanyak 207 orang peserta didik. Instrumen yang digunakan dalam bentuk angket sebanyak 30 butir pernyataan dan sudah divalidasi secara empirik. Analisis data hasil penelitian dilakukan secara deskriptif dan inferensial menggunakan ujit, dengan terlebih dahulu menguji normalitas dan homogenitas. Berdasarkan pengolahan data, diperoleh simpulan terdapat pengaruh yang signifikan dari minat belajar tinggi terhadap prestasi belajar matematika pada peserta didik kelas X di SMK Negeri 1 Cikarang Barat, Kab. Bekasi, Jawa Barat. Hal ini dapat dibuktikan dengan perolehan nilai $\boldsymbol{t}_{\text {hitung }}>\boldsymbol{t}_{\text {tabel }}$ yaitu 6,610 $>1,960$

\footnotetext{
Correspondence Address: Jl. Raya Tengah No.80Gedong, Pasar Rebo, Jakarta Timur, 13760, Indonesia; e-mail: nadun@gmail.com

How to Cite (APA $6^{\text {th }}$ Style): Nadun (2017). Pengaruh Minat Belajar Siswa Terhadap Hasil Belajar Trigonometri. JKPM (Jurnal Kajian Pendidikan Matematika), 03(01), 67-76

Copyright: Nadun, (2017)

Competing Interests Disclosures: The authors declare that they have no significant competing financial, professional or personal interests that might have influenced the performance or presentation of the work described in this manuscript.
} 


\section{PENDAHULUAN}

Semakin bertambah pesat perkembangan teknologi sehingga mampu mengubah gaya hidup masyarakat sebagai pengguna teknologi. Di bidang pendidikan, khususnya pada kegiatan pembelajaran harus sejalan untuk mengikuti perkembangan teknologi, khususnya teknologi elektronik dan komunikasi. Oleh karena itu, guru sebagai praktisi pendidikan dituntut untuk dapat berupaya mengembangkan, memilih, dan menggunakan berbagai hal terkait dengan teknologi pembelajaran serta mampu menggunakan teknologi elektronik dan komunikasi untuk menyampaikan ilmunya kepada siswa, khususnya pada mata pelajaran Matamatika yang oleh sebagian besar siswa dianggap ilmu yang sulit untuk dipelajari.

Dengan demikian,terlihat jelas peranan guru sebagai tenaga pendidik dalam menyiapkan tenagatenaga terampil untuk memenuhi tuntutan perkembangan teknologi, tidak boleh asing terhadap teknologi. Guru bukan hanya tidak boleh asing dengan teknologi, bahkan justru sebaliknya, guru harus akrab dengan teknologi yang relevan dan semaksimal mungkin menggunakannya sebagai media pembelajaran. Pendidikan merupakan rangkaian peristiwa yang sifatnya kompeks. Dalam peristiwa ini banyak faktor yang saling memengaruhi dan sekaligus saling menunjang satu sama lain. Salah satu faktor utama dalam pendidikan adalah siswa, yang mana melalui pendidikan, siswa diharapkan dapat tumbuh menjadi pribadi yang utuh dengan berkembang segenap potensinya melalui kegiatan pembelajaran.

Pembelajaran merupakan rangkaian kegiatan komunikasi antara manusia, yaitu orang yang belajar (siswa) dan orang yang mengajar (guru). Komunikasi antara dua subjek belajar tersebut, yaitu guru dan siswa adalah komunikasi yang dipengaruhi oleh berbagai faktor. Faktor-faktor itu antara lain, situasi dan kondisi pengajaran, kemampuan yang dimiliki guru, metode, mediadan lain sebagainya.

Guru sangat dibutuhkan untuk memberikan bekal hidup yang bermanfaat pada siswanya. Guru harus mampu memberikan berbagai bekal dalam situasi-situasi tertentu secara edukatif, sehingga dapat menciptakan situasi belajar mengajar yang kondusif. Seorang guru dalam kegiatan pembelajaran tidak sekadar mempertontonkan berbagai fakta dan juga tidak sekadar menyampaikan beragam informasi kepada siswa, atau memakai pendekatan otoriter dan doktrin yang hanya memerintah dan memaksa secara satu arah.

Cara mengajar guru dengan menggunakan berbagai teknik pengajaran, yang didasarkan pengertian dari pihak guru, akan dapat memperbesar minat siswa dalam belajar,sehinggabesar kemungkinan akan mempertinggi hasil belajar mereka.Dengan mengajak, merangsang, dan memberikan stimulasi pada siswa untuk ikut serta mengemukakan pendapat, belajar mengambil simpulan, belajar dalam kelompok, berdiskusi, dan lain-lain berarti membawa siswa pada suatu makna belajar yang sesungguhnya, dan bukan pada suasana belajar yang sifatnya kamuflase.

Matematika diakui penting perannya, karena pada ilmu pengetahuan lain, Matematika dijadikan sebagai ilmu alat, namun bagi sebagian besar siswa menganggapnya sulit dipelajari. Banyak siswa tidak suka belajar matematika, namun karena tuntutan kurikulum, sehingga mau tidak mau mereka harus memelajarinya baik suka maupun tidak suka. Keadaan di mana siswa belajar alakadarnya tanpa minat yang baik menjadikan hasil belajar untuk pelajaran Matematika yang juga alakadarnya. Atau dengan kata lain, besar kemungkinan manakala minat siswa tinggi dalam belajar Matematika, akan tinggi pula hasil belajar yang diraihnya.

Seperti telah dikemukakan diatas, salah satu dari faktor yang memengaruhi kegiatan pembelajaran adalah minat belajar siswa. Penelitian tentang minat belajar Matematika sudah banyak dilakukan, hasil penelitiannya pun cenderung merujuk pada satu simpulan yang sama, yaitu minat belajar Matematika yang tinggi akan menjadikan hasil belajar Matematika yang tinggi. Secara tegas, Siagian (2012) menyatakan 
bahwa prestasi belajar matematika dipengaruhi minat belajar siswa. Kemudian, Lestari (2013) menyatakan bahwa terdapat pengaruh yang signifikan antara minat belajar terhadap hasil belajar matematika.

Sedianya, bisa diprediksi untuk penelitian tentang minat belajar Matematika dari peserta didik akan memengaruhi prestasi belajarnya. Namun, bidang pendidikan itu sifatnya pragmatis, tidak bergantung pada satu faktor saja, akan tetapi sangat bergantung pada banyak faktor. Salah satu faktor yang menjadikan pertimbangan untuk terus dilakukan penelitian tentang minat belajar adalah faktor karakteristik peserta didik, yang mana dari satu tempat belajar dengan tempat belajar yang lain akan berbeda untuk karakteristik peserta didiknya. Atau dengan kata lain, sekalipun minat belajar yang dimiliki oleh seorang siswa itu tinggi, manakala karateristik daripada siswa tersebut cenderung 'special', maka besar kemungkinan faktor yang dominan atas hasil belajar matematikanya adalah karakteristik, buka lagi minat belajarnya.

Oleh karena sifat pragmatis dari bidang pendidikan, khususnya kegiatan pembelajaran Matematika, peneliti di sini berasumsi bahwa tidak ada satu kepastian tunggal yang menjamin prestasi belajar Matematika dari peserta didik dipengaruhi oleh minat belajarnya. Atau dengan kata lain, masih ada kemungkinan minat belajar Matematika dari peserta didik tidak memengaruhi prestasi belajarnya. Karena memungkinkan prestasi belajar Matematika dipengaruhi oleh banyak faktor lain, selain dari faktor minat belajar.

\section{METODE}

Penelitian dengan metode expose factoini dilaksanakan pada peserta didik kelas X di SMK Negeri 1 Cikarang Barat, Kab. Bekasi. . Adapun kelas yang diteliti adalah kelas X.3 dan X.4. dengan kondisi kemampuan kedua kelas tersebut relatif sama, dimana kedua kelas tersebut bukan kelas unggulan. Dalam penelitian ini, terdapat dua variabel yaitu minat belajarsiswa dan hasil belajar trigonometri. Untuk variabelminat belajarsiswa itu dikategorikan menjadi dua yaitu minat belajartinggi dan minat belajarrendah. Penelitian ini berusaha untuk mengungkap fakta hasil belajar trigonometrisiswa yang didasari dari minat belajartinggi dan minat belajar rendah. Adapun desain penelitian digambarkan sebagai berikut:

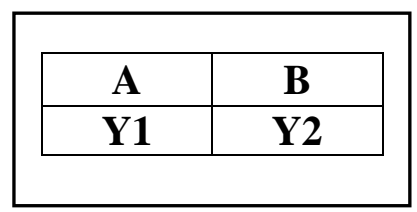

\section{Gambar 1. Desain Penelitian}

Keterangan:

A : Kelompok peserta didik minat belajartinggi.

B : Kelompok peserta didik minat belajarrendah.

Y1 : Hasil belajar trigonometrisiswa minat belajartinggi.

Y2 : Hasil belajar trigonometrisiswa minat belajar rendah.

Populasi target dari penelitian ini adalah seluruh peserta didik kelas X di SMK Negeri 1 Cikarang Barat, Kab. Bekasi. , yang terdiri dari 200 orang peserta didik. Adapun Populasi terjangkau dari penelitian ini adalah peserta didik kelas X.3 dan X.4yang berjumlah 60 orang peserta didik. Sampel dalam penelitian ini diambil dari populasi terjangkau dengan teknik random untuk dijadikan subjek penelitian. Oleh karena jumlah populasi pada populasi terjangkau sudah diketahui, jumlah sampel yang diambil pada penelitian ini diambil adalah 60 orang siswa yang akan terpisahkan untuk kelompok hasil belajar trigonometrisiswa minat belajartinggi dan kelompok hasil belajar trigonometrisiswa minat belajarrendah. 
Penelitian ini merupakan penelitian yang membandingkan hasil belajar trigonometrisiswa antara kelompok siswa dengan minat belajar tinggi dan kelompok siswa dengan minat belajar rendah.Minat belajar adalah skor minat belajar dari siswa yang diperoleh dari hasil penyebaran angket minat belajar trigonometri sebanyak 30 butir pernyataan dalam angket dengan skala pengukuran 1 s.d. 5 untuk tiap butir angket, yang meliputi aspek: keinginan belajar trigonometri,persiapan belajar, kesadaran mengulang kembali proses pembelajaran trigonometri dengan bantuan compact disk animasi matematika,anggapan positif dan negatif terhadap pembelajaran,dorongan dari orangtua,penghargaan,bantuan dari orang lain serta lingkungan belajar, yang selanjutnya diolah untuk mengelompokkan siswa kedalam kelompok minat belajar tinggi dan minat belajar rendah.

Sedangkan pengumpulan data hasil belajar trigonometri siswa diperoleh berdasarkan skor yang diperoleh siswa setelah melalui serangkaian proses pembelajaran, kemudian diberikan tes evaluasi untuk setiap sub pokokbahasan "trigonometri" sebanyak 20 butir soal pillihan ganda. Soal tes disusun sedemikian rupa sehingga mampu mewakili berbagai karakteristik dan aspek kognitif yang meliputi tingkat pengetahuan (C1), pemahaman (C2), dan penerapan (C3).Soal pilihan ganda materi trigonometri disusun berdasarkan uaraian materi berikut: perbandingan trigonometri segitiga siki-siku, nilai perbandingan trigonometri dari sudut-sudut khusus, perbandingan trigonometri dari sudut di semua kuadran, fungsi trigonometri dan grafiknya, persamaan trigonometri yang sederhana, identitas trigonometri, aturan sinus dan aturan kosinus, dan rumus luas segitiga.

Teknik analisis terhadap data hasil penelitian yang dalam hal ini berupa nilai hasil belajar trigonometri siswa dilakukan secara deskriptif dan inferensial. Secara deskriptif, data hasil penelitian dianalisis untuk skor mean, median, dan modus. Adapun maksud analisis skor mean, median, dan modus adalah untuk mendeskripsikan perolehan ukuran pemusatan data dari siswa yang menjadi subjek penelitian. Secara inferensial, data hasil penelitian dianalisis menggunakan ujit, dengan terlebih dahulu diuji untuk persyaratan analisisnya yaitu uji normalitas dan uji homogenitas.

\section{HASIL}

Penelitian ini dilakukan di SMK Negeri 1 Cikarang Barat, Kab. Bekasi. . Adapun yang menjadi objek dalam penelitian ini adalah peserta didik kelas X.3 sebagai dan kelas X.4 yang masing-masing berjumlah 30 orang, sehingga banyaknya responden yang diteliti seluruhnya berjumlah 60 orang siswa.Siswa yang menjadi sampel penelitian, ditinjau dari berbagai aspek sangat heterogen. Selain siswa berasal dari suku dengan beragan budaya berbeda-beda, mereka memiliki perbedaan karakteristik terutama dalam ranah kognitifnya. Selain itu, secara kasat mata berdasar pada hasil observasi di tempat penelitian, minat belajar dari siswa dalam mengikuti kegiatan belajar matematika sangat berbeda satu dengan yang lain. Oleh sebab itu, peneliti tertarik melakukan penelitian ini untuk mengetahui seberapa besar pengaruh minat belajar terhadap hasil belajar trigonometri.

Data yang dideskripsikan dan dianalisis dalam penelitian ini merupakan data yang diperoleh dari penyebaran instrumen tes pilihan ganda untuk materi trigonometri sebanyak 20 butir soal. Adapun data yangdisajikan berupa skor perolehan jawaban benar atas instrumendari siswa yang menjadi sampel penelitian. Berikut ini data hasil penelitian yang sudah terpisah berdasarkan siswa kelompok minat belajar tinggi dan kelompok minat belajar rendah.

Hasil belajar trigonometri yang diperoleh dari 30orang siswa berkisar antara skor7 sampai dengan 20. Berdasarkan data tersebut dibuat perhitungan untuk nilai rata-rata, median, modus, varians, dan simpangan baku. Adapun data hasil belajar trigonometriyang dicapai siswa pada kelompok minat belajar tinggiditampilkan pada tabel 1 . 


\section{Tabel 1. Ringkasan Hasil Perhitungan Statistik Deskriptif Hasil Belajar Trigonometri Kelompok Minat Belajar Tinggi}

\begin{tabular}{lc}
\multicolumn{1}{c}{ Data Statistik } & Prestasi Belajar Matematika \\
\hline SkorTerendah & 7 \\
\hline SkorTertinggi & 20 \\
\hline Range & 13 \\
\hline Mean & 13,20 \\
\hline Median & 13,50 \\
\hline Modus & 14 \\
\hline Varians & 11,545 \\
\hline Standar Deviasi & 3,398 \\
\hline Simpangan Baku & 0,620 \\
Sumber: Data primer yang diolah &
\end{tabular}

Hasil belajar trigonometri yang diperoleh dari 30orang siswa berkisar antara skor7 sampai dengan 15. Berdasarkan data tersebut dibuat perhitungan untuk nilai rata-rata, median, modus, varians, dan simpangan baku. Adapun data hasil belajar trigonometri yang dicapai siswa pada kelompok minat belajar tinggiditampilkan pada tabel 2 .

\section{Tabel 2. Ringkasan Hasil Perhitungan Statistik Deskriptif Hasil Belajar trogonometri Kelompok Minat Belajar Rendah}

\begin{tabular}{lc}
\multicolumn{1}{c}{ Data Statistik } & Prestasi Belajar Matematika \\
\hline Skor Terendah & 7 \\
\hline Skor Tertinggi & 15 \\
\hline Range & 8 \\
\hline Mean & 10,50 \\
\hline Median & 10,00 \\
\hline Modus & 10 \\
\hline Varians & 4,810 \\
\hline Standar Deviasi & 2,193 \\
\hline Simpangan Baku & 0,400 \\
Sumber: Data primer yang diolah &
\end{tabular}

Prasyarat dalam menganalisis data yang pertama dilakukan adalah uji normalitas. Uji normalitas dilakukan untuk mengetahui normal tidaknya distribusi data yang akan dianalisis. Uji normalitas data dapat dilakukan dengan berbagai cara, diantaranya: uji kertas peluang normal, uji Liliefors, dan uji Chi kuadrat. Pada penelitian ini, peneliti menggunakan uji Chi kuadrat.

Hasil Uji Normalitas Data untuk Kelompok Hasil Belajar trogonometri Kelompok Minat Belajar Tinggi.

Perhitungan uji normalitas data yaitu mencari nilai Chikuadrat hitung untuk dibandingkan dengan nilai Chikuadrattabel. Adapun kriteria pengujian normalitas dengan chi kuadrat adalah: "Jika $X^{2}{ }_{\text {hitung }}<X^{2}$ tabel, 
terima $\mathrm{H}_{0}$ atau Data Berdistribusi Normal, namunJika $\chi^{2}$ hitung $>\chi^{2}$ tabel, tolak $\mathrm{H}_{0}$ atau Data Tidak Berdistribusi Normal”. Berdasarkan hasil perhitungan uji Chikuadrat, diperoleh bahwa nilai untuk $\chi^{2}$ hitung $=8,2061$. Kemudian dari daftar tabel Chikuadrat, untuk $\alpha=0,05$ dan $\mathrm{n}=7$ didapat nilai $X^{2}$ tabel $=14,0671$. Dengan demikian dapat dinyatakan bahwa data untuk kelompok hasil belajar trogonometri kelompok minat belajar tinggiberasal dari populasi yang berdistribusi normal, karena $X^{2}$ hitung $<X^{2}$ tabel yaitu 8,2061< 14,0671 .

Hasil Uji Normalitas Data untuk Kelompok Hasil Belajar trogonometri Kelompok Minat Belajar Rendah.

Perhitungan uji normalitas data yaitu mencari nilai Chikuadrat hitung untuk dibandingkan dengan nilai Chikuadrattabel. Adapun kriteria pengujian normalitas dengan chi kuadrat adalah: "Jika $\chi^{2}{ }_{\text {hitung }}<$ $\chi^{2}$ tabel, terima $\mathrm{H}_{0}$ atau Data Berdistribusi Normal, namunJika $\chi^{2}$ hitung $>\mathcal{X}^{2}$ tabel, tolak $\mathrm{H}_{0}$ atau Data Tidak Berdistribusi Normal". Berdasarkan hasil perhitungan uji Chikuadrat, diperoleh bahwa nilai untuk $\chi^{2}$ hitung $=5,9920$. Kemudian dari daftar tabel Chikuadrat, untuk $\alpha=0,05$ dan $\mathrm{n}=7$ didapat nilai $\mathcal{X}^{2}$ tabel $=14,0671$. Dengan demikian dapat dinyatakan bahwa data untuk kelompok hasil belajar trogonometri kelompok minat belajar rendahberasal dari populasi yang berdistribusi normal, karena $X^{2}{ }_{\text {hitung }}<X^{2}$ tabel yaitu 5,9920< 14,0671 .

\section{Uji Homogenitas Varians}

Setelah data pada kedua kelompok sampel pada penelitian ini dinyatakan berasal dari populasi yang berdistribusi normal, selanjutnya dilakukan uji homogenitas varians untuk kedua kelompok data tersebut dengan uji Fisher. Uji homogenitas ini dilakukan untuk mengetahui apakah kedua kelompok data memiliki varians yang homogen atau tidak.

Pasangan hipotesis yang akan diuji adalah sebagai berikut:

$$
\begin{aligned}
& H_{0}: \sigma_{1}{ }^{2}=\sigma_{2}{ }^{2} \\
& H_{1}: \sigma_{1}{ }^{2} \neq \sigma_{2}{ }^{2}
\end{aligned}
$$

Keterangan:

$$
\begin{aligned}
& \sigma_{1}^{2}: \text { Varians kelompok internal locus of control } \\
& \sigma_{2}^{2} \text { : Varians kelompok eksternal locus of control }
\end{aligned}
$$

Maka:

1) Berdasarkan deskripsi data di atas, untuk kelompok internal locus of control dan eksternal locus of control didapat:

Varians kelompok internal locus of control: $s^{2}=55,36$

Varians kelompok eksternal locus of control: $s^{2}=38,88$

2) Menghitung Nilai $F_{\text {hitung }}$

$$
F_{\text {hitung }}=\frac{\text { Varians Terbesar }}{\text { Varians Terkecil }}=\frac{55,36}{38,88}=1,4239
$$

Kemudian diketahui pada tabel distribusi $F$ untuk $\alpha=0,05$ dengan $\mathrm{dk}_{\text {pembilang }}=8-1=7$ dan untuk $\mathrm{dk}_{\text {penyebut }}$

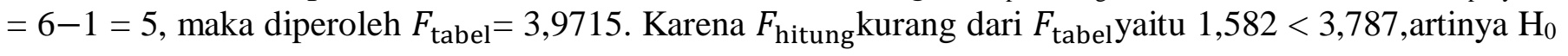
diterima, sehingga dapat disimpulkan bahwa kedua kelompok data memiliki varians yang sama atau homogen.

Berdasarkan data kelompok internal locus of control dan data kelompok eksternal locus of control, diperoleh informasi bahwa nilai rata-rata untuk data kelompok internal locus of control adalah 75,60 dan 
nilai rata-rata untuk data kelompok eksternal locus of control adalah 67,13. Informasi lain yaitu tentang skor varians, dimana varians untuk data kelompok internal locus of control adalah 55,36 dan varians untuk data kelompok eksternal locus of control adalah 38,88. Adapun banyaknya sampel untuk kelompok internal locus of control adalah 135 dan banyaknya sampel untuk kelompok internal locus of control adalah 41.

Hipotesis yang akan diuji pada penelitian ini adalah apakah prestasi belajar matematika kelompok peserta didik internal locus of control tidak lebih tinggi atau sama dengan prestasi belajar matematika kelompok peserta didik eksternal locus of control. Untuk mengetahui lebih lanjut atas hal tersebut, maka perlu dilakukan pengujian perbedaan rata-rata dua kelompok data. Untuk itu pengujian hipotesis dilakukan dengan menggunakan uji $\boldsymbol{t}$. Adapun rumus untuk uji $\boldsymbol{t}$ nya ditetapkan sebagai berikut:

$$
\begin{aligned}
& \boldsymbol{t}=\frac{\bar{X}_{A}-\bar{X}_{B}}{\mathrm{~S}_{\mathrm{gab}} \sqrt{\frac{1}{n_{A}}+\frac{1}{n_{B}}}} ; \\
& \text { Dengan: } \\
& \mathrm{S}_{\mathrm{gab}}{ }^{2}=\frac{\left(n_{A}-1\right) s_{A}{ }^{2}+\left(n_{B-1}\right) s_{B}{ }^{2}}{n_{A}+n_{B}-2}
\end{aligned}
$$

Berdasarkan informasi yang diperoleh dari perhitungan nilai rata-rata, perhitungan skor varians, dan jumlah sampel untuk masing-masing kelompok data, diketahui sebagai berikut:

$$
\begin{aligned}
& S_{A}{ }^{2}=55,36 \quad \bar{X}_{\mathrm{A}}=75,60 \quad n_{A}=135 \\
& S_{B}{ }^{2}=38,88 \quad \bar{X}_{\mathrm{B}}=67,13 n_{B}=41 \\
& \begin{array}{c}
\text { Maka: } \\
S_{\text {gab }}=\sqrt{\frac{((134) \cdot(55,36))+((40) \cdot(38,88))}{135+41-2}} \\
S_{g a b}=\sqrt{\frac{7418,24+1555,20}{174}} \\
S_{g a b}=\sqrt{\frac{8973,44}{174}} \\
S_{\text {gab }}=\sqrt{51,57} \\
\text { Sgab }=7,18
\end{array} \\
& \text { Sehingga: } \\
& t=\frac{\overline{\mathrm{X}_{1}}-\overline{\mathrm{X}_{2}}}{\mathrm{~S}_{\mathrm{gab}} \sqrt{\frac{1}{\mathrm{n}_{1}}+\frac{1}{\mathrm{n}_{2}}}} \\
& \boldsymbol{t}=\frac{75,60-67,13}{7,18 \times \sqrt{\frac{1}{135}+\frac{1}{41}}} \\
& \boldsymbol{t}=\frac{8,47}{7,18 \times \sqrt{0,0318}} \\
& \boldsymbol{t}=\frac{8,47}{7,18 \times 0,18} \\
& \boldsymbol{t}=\frac{8,47}{1,28}
\end{aligned}
$$


Selanjutnya nilai $\boldsymbol{t}_{\text {hitung }}$ dibandingkan dengan nilai dari tabel distribusi $\boldsymbol{t}\left(\boldsymbol{t}_{\text {tabel }}\right)$. Didasarkan pada taraf signifikansi pada $\alpha=0,05 \mathrm{dan} \mathrm{dk}=\mathrm{n}_{1}+\mathrm{n}_{2}-2$ akan didapat nilai $\boldsymbol{t}_{\text {tabel }}$. Karena $\mathrm{dk}=174$, nilai $\boldsymbol{t}_{\text {tabel }}$ adalah 1,960. Hasil perhitungan didapatkan $\left(\boldsymbol{t}_{\text {hitung }}>\boldsymbol{t}_{\text {tabel }}\right)$. yaitu 6,61 $>1,960$. Dengan demikian $\mathrm{H}_{0}$ yang menyatakan prestasi belajar matematika kelompok peserta didik internal locus of control tidak lebih tinggi atau sama dengan prestasi belajar matematika kelompok peserta didik eksternal locus of control adalah ditolak. Dengan kata lain, $\mathrm{H}_{1}$ diterima yaitu prestasi belajar matematika kelompok peserta didik internal locus of control lebih tinggi daripada prestasi belajar matematika kelompok peserta didik eksternal locus of control. Oleh karena itu, dapat dinyatakan prestasi belajar matematika kelompok peserta didik internal locus of control lebih baik daripada prestasi belajar matematika kelompok peserta didik eksternal locus of control. Berdasarkan hal tersebut, dapat pula dinyatakan bahwa terdapat pengaruh yang signifikan locus of control terhadap prestasi belajar matematika.

\section{PEMBAHASAN}

Lestari (2013) menyatakan bahwa seseorang dengan minat belajar yang tinggi tidak akan menjadikan hambatan sebagai halangan atau kendala dalam belajar, mereka yang berminat tinggi tidak akan mengalami kendala dalam belajar.

Berdasarkan pada perhitungan data hasil penelitian yang dilaksanakan di SMK Negeri 1 Cikarang Barat, Kabupaten Bekasi dan berdasarkan pada hasil perhitungan pengujian hipotesis penelitian, dinyatakan bahwa prestasi belajar matematika kelompok peserta didik internal locus of control lebih baik daripada prestasi belajar matematika kelompok peserta didik eksternal locus of control. Dengan kata lain, dapat pula dinyatakan bahwa terdapat pengaruh yang signifikan locus of control terhadap prestasi belajar matematika.

Ciri-ciri locus of control internal, diantaranya: merasa mampu untuk mengatur segala tindakan, perbuatan dan lingkunganya; rajin, ulet, mandiri dan tidak mudah terpengaruh begitu saja terhadap stimulasi yang datang dari luar; lebih bertanggung jawab terhadap kesalahan dan kegagalan; lebih efektif dalam menyelesaikan tugas; dan memiliki kepercayaan tinggi akan kemampuan dirinya. Adapun ciri-cirilocus of control eksternal, diantaranya: lebih pasrah dan bersikap comforming dengan lingkungan; merasa bahwa perbuatan kecilnya berpengaruh terhadap kejadian yang akan dihadapi, baik untuk menjadi situasi yang tidak menyenangkan maupun dalam usaha untuk mencapai tujuan; kurang bertanggung jawab terhadap kesalahan yang diperbuat; kurang percaya diri terhadap kemampuanya; dan cenderung mengandalkan orang lain.

Wujud karakter dari locus of control internal yakni mempunyai dua karateristik pokok yaitu motivasi berprestasi tinggi dan independent. Seseorang dengan locus of control internal akan cenderung pada pengertian prestasi dan mempunyai tolerasi terhadap penundaan hadiah serta cenderung merencanakan segala sesuatu dalam jangka panjang. Setiap personal yang memiliki kecenderungan locus of control internal akan menyebabkan personal tersebut cenderung untuk melakukan evaluasi atas kinerjanya. Kemudian, seseorang denganlocus of control eksternal biasanya kurang memberikan arti mengenai tujuan kegagalan yang terjadi pada dirinya. Seseorang denganlocus of control eksternal cenderung lebih mengharapkan keberhasilan dari keberuntungan. Setiap personal yang memiliki kecenderungan locus of control eksternal akan senantiasa memainkan harapan tanpa evaluasi atas kinerjanya.

Pendidikan merupakan salah satu hal penting dalam kehidupan berbangsa dan bernegara, dimana dengan pendidikian akan menghasilkan sumber daya manusia berkualitas. Adapun sumber daya manusia berkualitas yaitu sumber daya manusia yang mampu bersaing dalam menghadapi segala macam perkembangan dan kemajuan kehidupan berbangsa dan bernegara. Melihat begitu pentingnya pendidikan, 
menjadikan pendidikan sebagai hal yang wajib dilaksanakan secara berkesinambungan guna menjawab tantangan zaman.

Menciptakan pendidikan yang berkualitas bukan hanya mengandalkan pemerintah melainkan membutuhkan dukungan dari semua pihak, seperti masyarakat umum, segenap orangtua dan wali murid, segenap dewan guru, tenaga kependidikan, sarana dan prasarana pendidikan dan juga peserta didik. Beberapa faktor pendukung prestasi belajar matematika pada peserta didik antara lain: mempunyai task commitment yang tinggi, memiliki locus of control internal, disiplin, konsisten diri yang baik, minat belajar yang tinggi, dan lain sebagainya. Di sisi lain, tidak semua peserta didik menyukai matematika, karena matematika dianggap oleh peserta didik sebagai mata pelajaran yang membosankan serta sukar dan sulit dalam menyelesaikan soal-soalnya.

Hal tersebut seperti di atas, disebabkan karena peserta didik sudah menganggapnya membosankan, menakutkan, bersifat abstrak, penuh dengan angka-angka dan rumus. Selain itu juga karena masih ada sistem belajar yang menyamakan kemampuan peserta didik, kurangnya motivasi dari guru, metode pembelajaran yang kurang menarik dan membosankan. Seperti yang dijelaskan sebelumnya, beberapa faktor yang mempengaruhi prestasi belajar peserta didik salah satunya locus of control. Penelitian ini sudah menunjukkan bahwa locus of control berpengaruh signifikan terhadap prestasi belajar matematika peserta didik.

Locus of control pada peserta didik harus senantiasa ditanamkan, dibangun, dan terjaga untuk ditingkatkan. Hal yang paling lazim dapat dilakukan berkenaan dengan locus of control peserta didik adalah selalu belajar tanpa disuruh oleh orang lain, baik itu guru atau teman atau bahkan orang tua. Peserta didik harus mulai bisa mengendalikan dirinya sendiri dalam hal belajar tanpa disuruh, karena kendali diri ini makna atas locus of control.

Locus of control pada peserta didik dapan dibangun dengan menanamkan suatu kendali diri berupa keyakinan dalam diri bahwa belajar dengan rajin akan mampu meraih kesuksesan berupa prestasi belajar yang jauh lebih baik. Berhasilnya diri peserta didik dalam belajar matematika disebabkan oleh karena usaha yang dilakukan sendiri oleh peserta didik berupa rajin belajar tanpa disuruh. Locus of control pada peserta didik juga dapat dijaga dengan terus berusaha memecahkan soal matematika yang sulit, tanamkan pada diri peserta didik bahwa peserta didik yakin bisa mengerjakan soal matematika yang sulit.

\section{SIMPULAN}

Berdasarkan hasil penelitian yang diperoleh dengan menggunakan uji $\boldsymbol{t}$, yaitu ditolaknya $\mathrm{H}_{0}$ dan diterimanya $\mathrm{H}_{1}$, disimpulkan bahwa prestasi belajar matematika kelompok peserta didik internal locus of control lebih baik daripada prestasi belajar matematika kelompok peserta didik eksternal locus of control. Dengan kata lain, simpulan dari penelitian ini adalah terdapat pengaruh yang signifikan locus of control terhadap prestasi belajar matematika peserta didik kelas X di SMK Negeri 1 Cikarang Barat, Kabupaten Bekasi.

Berdasarkan penelitian yang sudah selesai dilaksakan, ada beberapa hal berupa saran yang dapat peneliti sampaikan, diantaranya bagi Kepala Sekolah dan Supervisor/ Pengawas Sekolah, serta Ketua MGMP Matematika,hasil penelitian ini sebagai informasi untuk lebih meningkatkan kualitas mutu pendidikan pada pelajaran matematika. Bagi segenap dewan guru mata pelajaran matematika, hasil penelitian ini dijadikan informasi yang dapat digunakan sebagai dasar pemikiran bahwa prestasi belajar matematika dipengaruhi signifikan oleh locus of control.Bagi orangtua peserta didik, hasil penelitian ini dapat dijadikan landasan bahwasanya orangtua sebagai teladan utama dalam membangun konsep locus of 
76 Nadun

control pada diri peserta didik, yang pada akhirnya prestasi belajar matematika peserta didik dapat menjadi lebih baik lagi.

\section{DAFTAR PUSTAKA}

Lestari, I. 2013. Pengaruh Waktu Belajar dan Minat Belajar terhadap Hasil Belajar Matematika. Formatif, 3 (2): $115-125$.

Siagian, R. E. F. 2012. Pengaruh Minat dan Kebiasaan BelajarSiswa terhadap Prestasi Belajar Matematika. Formatif, 2 (2): 122-131. 